\title{
Sistem Penunjang Keputusan Jabatan Fungsional Akademik Tenaga Pendidik di STIE Kesatuan
}

\author{
Pingky Dezar Zulkarnain 1 , Yanto Hermawan² \\ DOl: https://doi.org/10.36339/jaspt.v5i1.416
}

\begin{abstract}
One important part of the rank of an educator at STIE Kesatuan is required to understand the processes in applying for promotion by completing complete documents, consisting of education and teaching, scientific work, community service and support. So far, the process of increasing the functional position of educators is based on the results of the processing carried out based on the work unit in the HRD. For the sake of appropriateness of the process of increasing the academic position of lecturers and the suitability of the points required, a support system for the decision to increase in academic functional positions is made for educators. The data used are in the form of previous rank files along with educational and teaching files, scientific papers, community service and support. The econometric analysis method is used to calculate statistically. The test results carry out structural and functional checks to determine whether the system being made is in accordance with the design or not.
\end{abstract}

1. Program Studi Sistem Informasi, Institut Bisnis dan Informatika Kesatuan

2. Program Studi Sistem Informasi, Institut Bisnis dan Informatika Kesatuan, Jalan Ranggagading No. 1 Bogor West Java, Indonesia

Email of Corresponding Author : anto@ibik.ac.id

Keywords: Decision support systems, Data flow diagram

\section{PENDAHULUAN}

Lembaga pendidikan perguruan tinggi, tenaga pendidik menjadi salah satu faktor penunjang kemajuan bidang pendidikan, penelitian dan pengabdian masyarakat. Tenaga pendidik merupakan orang yang diberikan tugas oleh penyelenggara perguruan tinggi untuk memeberikan pengajaran sesuai kompetensi yang dimiliki. Adapun kewajiban tenaga pendidik adalah melaksanakan Tridharma Perguruan Tinggi yaitu dengan melaksanakan Pendidikan, Pengajaran, melaksanakan Penelitian, melaksanakan Pengabdian Kepada Masyarakat, dan Unsur Penunjang. Berdasarkan unsur Tridharma Perguruan Tinggi yang dilaksanakan tersebut, maka tenaga pendidik berhak mendapatkan jabatan fungsional sesuai dengan jumlah angka kredit yang miliki.

Institut Bisnis dan Informatika Kesatuan adalah perguruan tinggi dibidang pendidikan yang memiliki 5 program studi, seperti Akuntansi S1, Manajemen S1, Keuangan dan Perbankan D3, Akuntansi D3 serta Manajemen Pemasaran D3 serta 4 Program Studi baru yaitu, Sistem Informasi, Teknologi Informasi, Biokewirausahaan dan Pariwisata, dan memiliki tenaga pendidik tetap sebanyak 95 orang tenaga pendidik, diantaranya 70 tenaga pendidik tetap sudah memilki jabatan fungsional akademik dan 25 orang tenaga pendidik tetap belum memilki jabatan fungsional akademik.

JAS-PT
JURNAL ANAUSIS SISTEM PPNDIDIKAN TINGG ISSN $2580-5339$ eISSN $2620-5718$
Volume 5 Nomor 1
JULI 2021
Hal $49-56$

DOSEN INDONESIA SEMESTA 
Saat ini penilaian tenaga pendidik dilihat dari aktivitas yang telah dilakukan tenaga pendidik berdasarkan pada pedoman penilaian angka kredit jabatan fungsional tenaga pendidik. Beberapa tenaga pendidik tidak melakukan pengajuan yang teratur dan disiplin. Aktivitas tenaga pendidik juga tidak terarah dalam pemenuhan unsur-unsur yang menjadi syarat kenaikan jabatan fungsional. Pengumpulan, pencatatan, penghitungan, dan penyusunan dokumen pengajuan masih dilakukan secara manual sehingga lambatnya pengajuan yang dilakukan tenaga pendidik. Monitoring aktivitas dan nilai yang diperoleh tidak dapat diketahui secara langsung.

Dari pembahasan diatas, STIE Kesatuan yang berhubungan dengan tenaga pendidik khususnya, mengenai isian angka kredit jabatan fungsional dari layanan manual dapat diubah menjadi layanan yang lebih efektif dan efisien melalui internet dengan memanfaatkan aplikasi web (web applications), untuk itu perlu adanya aplikasi web Kenaikan Jabatan Fungsional Akademik.

\section{METODE PENELITIAN}

Metode pengembangan sistem dalam penelitian ini menggunakan pendekatan model waterfall model klasik yang bersifat sistematis, berurutan dalam membangun sistem, dasar dari aktifitas proses yang terdiri dari spesifikasi, pengembangan, validasi, evolusi dan semua dipresentasikan dalam tahapan yang terpisah seperti spesifikasi kebutuhan, perancangan perangkat lunak, implementasi, pengujian, dan sebagainya. Model Waterfall ini merupakan sebuah proses yang bersifat perencanaan secara prinsip, semua aktivitas proses harus direncanakan dan diproses terlebih dahulu sebelum mulai mengerjakannya.

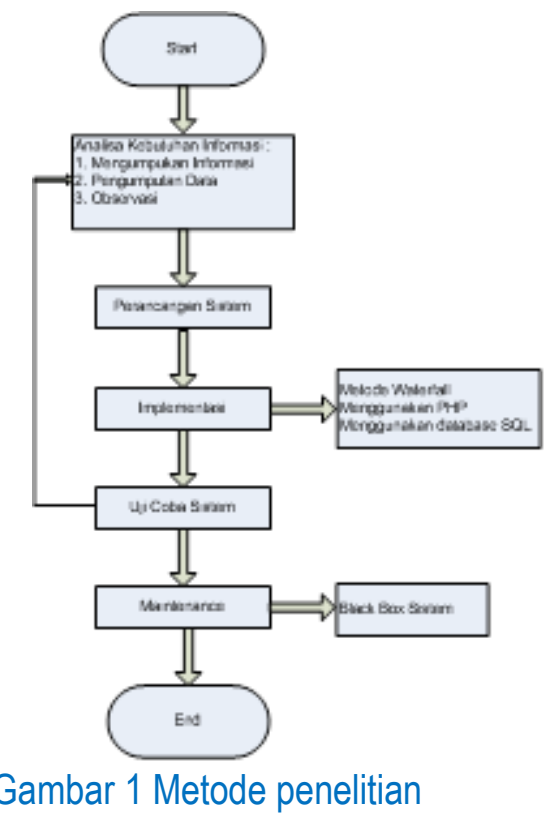

Analisis yang digunakan oleh penulis dalam menghubungkan variabel-variabel $X$ yaitu Pendidikan (X1), Karya IImiah (X2), Pengabdian (X3), dan Penunjang (X4) dengan

JAS-PT

JURNAL ANALISIS SISTEM PENDIDIKAN TINGGI ISSN $2580-5339$ eISSN $2620-5718$ Volume 5

Nomor 1 JULI 2021 Hal 49 - 56

DOSEN INDONESIA SEMESTA variabel $Y$ yaitu Keputusan Kenaikan Pangkat $(Y)$ dan variabel $Z$ yaitu Nilai yang dibutuhkan (Z). Analisis ini digunakan untuk membentuk variabel $Y$ dari variabel-variabel $X$ sehingga menghasilkan nilai dan nilai yang dihasilkan dapat dibandingkan variabel Z yaitu nilai minimal yang harus dipenuhi oleh tenaga pendidik yang mengajukan kenaikan kepangkatan agar dapat diajukan kenaikan kepangkatan dari tenaga pendidik yang bersangkutan.

Persamaan metode ekonometrika yang digunakan penulis sebagai berikut : 
$Y=0,35 X 1+0,25 X 2+0,15 X 3+0,25 X 4$

$Z=$ Nilai yang dibutuhkan/nilai minimal yang harus dipenuhi

Dimana : $\mathrm{X} 1=$ Pendidikan, $\mathrm{X} 2=$ Karya IImiah, $\mathrm{X} 3=$ Pengabdian, $\mathrm{X} 4=$ Penunjang

$Y=$ Total Nilai Keputusan Kenaikan Pangkat "Bisa Diajukan" atau "Tidak Bisa

Diajukan

Keputusan Kenaikan Pangkat:

a. Diterima/Diajukan jika $Y \geq Z$

b. Ditolak/Tidak Diajukan jika $Y<Z$

\section{HASIL DAN PEMBAHASAN}

Analisis kebutuhan dilakukan untuk mendefinisikan kebutuhan-kebutuhan sistem, meliputi: kebutuhan fungsional dan analisa kebutuhan pengguna. Pengguna sistem kenaikan jabatan fungsional tenaga pendidik terdiri yaitu Bagian HRD dan Senat. Bagian HRD mengelola kenaikan jabatan fungsional tenaga pendidik yang mempunyai hak untuk menginput data. Kemudian Senat yang mempunyai akses apakah tenaga pendidik tersebut sudah layak diajukan atau belum. Sedangkan masukan untuk melakukan input kenaikan jabatan fungsional yaitu berupa data data dari berbagai unsur kenaikan jabatan fungsional tenaga pendidik. Selain masukan sistem juga terdapat keluaran sistem yaitu bobot nilai dari setiap data inputan dengan cara menghitung jumlah angka kredit.

Berdasarkan proses bisnis yang sedang berjalan, tenaga pendidik yang ingin naik jabatan tenaga pendidik tidak dapat melihat secara langsung angka kredit berapa yang sudah didapatkan serta dalam redaksi dalam menentukan kenaikan masih dengan cara manual, sehingga proses kegiatan kenaikan jabatan tidak dapat dilakukan secara, praktis, cepat dan akurat karena tidak terkontrolnya proses kenaikan. Proses bisnis yang sedang berjalan ditunjukan pada gambar dibawah ini Proses Bisnis yang Sedang Berjalan Dalam Sistem Penunjang Kenaikan Jabatan Fungsional.

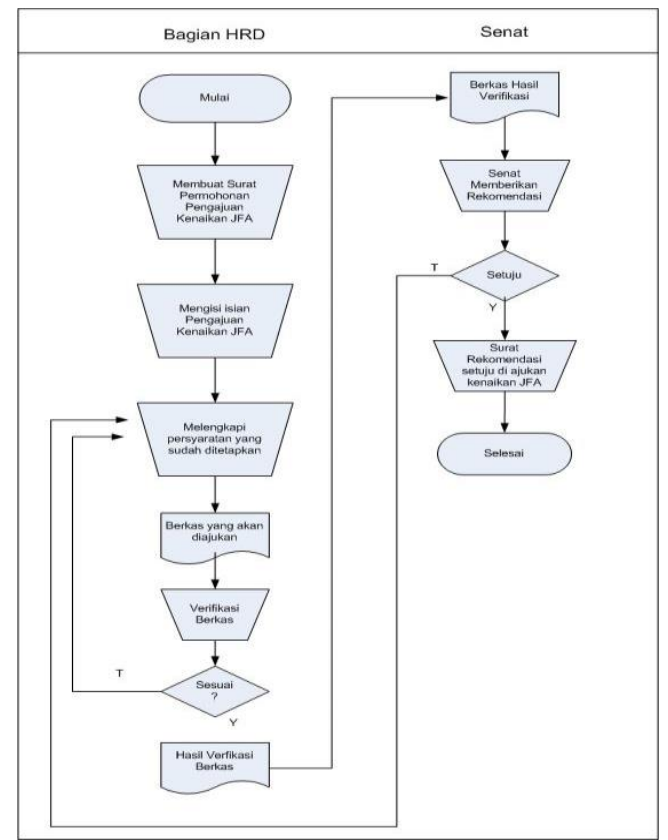

Gambar 2 Proses bisnis yang sedang berjalan

Berdasarkan proses bisnis sistem yang sedang berjalan, diperlukan database baru yang mampu menyimpan, menginformasikan dan mengolah kenaikan jabatan fungsional

JAS-PT

JURNAL ANAUSIS SISTEM PENDIDIKAN TINGG ISSN $2580-5339$ eISSN $2620-5718$ Volume 5 Nomor 1 JULI 2021 Hal 49 - 56

DOSEN INDONESIA SEMESTA 
tenaga pendidik, sehingga dibutuhkan sistem yang baru. Proses bisnis yang baru merupakan alur kegiatan proses yang dilakukan dengan menggunakan sistem baru.

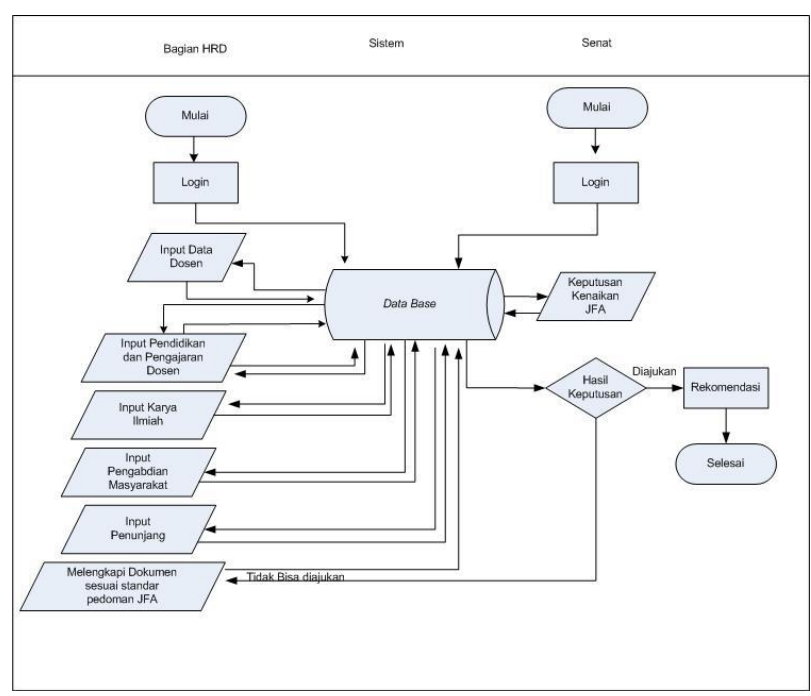

Gambar 3 Proses bisnis baru

Keputusan Kenaikan Pangkat bagi tenaga pendidik-tenaga pendidik STIE Kesatuan terbagi menjadi 2 yaitu "Bisa Diajukan" atau "Tidak Bisa Diajukan". Keputusan tersebut dibuat berdasarkan hasil nilai yang didapat setiap tenaga pendidik dari beberapa factor/variabel yang harus dipenuhi sehingga dapat dibandingkan dengan nilai yang dibutuhkan (nilai minimal) untuk dapat menaikkan jenjang kepangkatannya sesuai dengan jenjang kepangkatan yang diajukan. Adapun nilai yang dibutuhkan untuk dapat menaikkan jenjang kepangkatannya sesuai yang diajukan.

Tabel 1 Nilai yang Dibutuhkan dalam Keputusan Kenaikan Pangkat Tenaga pendidik

\begin{tabular}{|c|c|c|}
\hline No & Pangkat Tenaga pendidik & Nilai yang Dibutuhkan (minimal) \\
\hline 1 & Asisten Ahli & 100 \\
\hline 2 & Lektor & 100 \\
\hline 3 & Lektor Kepala & 200 \\
\hline 4 & Guru Besar & 450 \\
\hline
\end{tabular}

Berdasarkan tabel 1 keputusan kenaikan pangkat tenaga pendidik dapat diajukan apabila dapat memenuhi nilai minimal/nilai yang dibutuhkan untuk setiap pangkat tenaga pendidik yang diajukan. Apabila nilai yang didapat oleh tenaga pendidik yang bersangkutan tidak mencukupi/dibawah dari nilai yang dibutuhkan maka tenaga pendidik yang bersangkutan tidak bisa diajukan untuk kenaikan jenjang kepangkatan tenaga pendidik. Nilai yang dibutuhkan dalam pengajuan kenaikan jenjang kepangkatan tenaga pendidik dibentuk dari beberapa variabel dengan komposisi yang berbeda-beda. Variabel-variabel yang membentuk kepangkatan tenaga pendidik sebagai berikut :

1. Variabel $1(\mathrm{X} 1)=$ Pendidikan Kriteria Pemenuhan berdasar pada:

a. Tingkat Pendidikan dari tenaga pendidik yang bersangkutan;

b. Pengajaran yang dilakukan tenaga pendidik yang bersangkutan;

JAS-PT

JURNAL ANALISIS SISTEM PENDIDIKAN TINGG ISSN $2580-5339$ eISSN $2620-5718$

Volume 5

Nomor 1

JULI 2021

Hal 49 - 56

DOSEN INDONESIA SEMESTA c. Bimbingan kepada mahasiswa yang dilakukan tenaga pendidik yang bersangkutan;

d. Menjadi Penguji mahasiswa dalam seminar ataupun siding skripsi mahasiswa yang dilakukan tenaga pendidik yang bersangkutan;

e. Jabatan struktural yang dimiliki tenaga pendidik yang bersangkutan di Perguruan Tinggi masing-masing;

f. Orasi ilmiah yang dilakukan tenaga pendidik yang bersangkutan.

52 | JURNAL ANALISIS SISTEM PENDIDIKAN TINGGI | VOL. 4 NO. 1 2021, pp. 49-56 
2. Variabel $2(\mathrm{X} 2)=$ Karya Ilmiah Kriteria Pemenuhan berdasar pada:
a. Membuat jurnal ilmiah;
b. Membuat buku;
c. Membuat prosiding.

3. Variabel $3(X 3)=$ Pengabdian Kriteria Pemenuhan berdasar pada:

a. Menjadi narasumber dalam seminar ataupun pelatihan;

b. Menjadi penguji diluar Perguruan Tinggi dari homebase tenaga pendidik yang bersangkutan seperti menguji kompetensi siswa/siswi di SMA/SMK;

c. Memiliki jabatan di lingkungan lembaga pemerintahan.

4. Variabel $4(X 4)=$ Penunjang Kriteria Pemenuhan berdasar pada:

a. Menjadi peserta dalam seminar ataupun pelatihan baik di lingkungan Perguruan Tinggi tenaga pendidik yang bersangkutan maupun di luar Perguruan Tinggi tenaga pendidik yang bersangkutan;

b. Semester (UAS) di Perguruan Tinggi tenaga pendidik yang bersangkutan;

c. Menjadi panitia dalam berbagai kegiatan pendidikan seperti panitia penyelenggara ujian, panitia penyelenggara SPMI, panitia penyelenggara wisuda, dll.

Adapun komposisi yang harus dipenuhi setiap variabel pembentuk agar dapat mengajukan kenaikan kepangkatan tenaga pendidik sebagai berikut :

Tabel 2 komposisi variabel untuk mengajukan kenaikan kepangkatan tenaga pendidik

\begin{tabular}{|c|c|c|c|c|c|}
\hline $\mathbf{N}$ & $\begin{array}{c}\text { Pangkat Tenaga } \\
\mathbf{0}\end{array}$ & $\begin{array}{c}\text { Pendidika } \\
\text { pendidik }\end{array}$ & $\begin{array}{c}\text { Karya } \\
\text { Ilmiah }\end{array}$ & $\begin{array}{c}\text { Pengabdia } \\
\mathbf{n}\end{array}$ & $\begin{array}{c}\text { Penunjan } \\
\mathbf{g}\end{array}$ \\
\hline 1 & Asisten Ahli & $35 \%$ & $25 \%$ & $15 \%$ & $25 \%$ \\
\hline 2 & Lektor & $35 \%$ & $25 \%$ & $15 \%$ & $25 \%$ \\
\hline 3 & Lektor Kepala & $35 \%$ & $25 \%$ & $15 \%$ & $25 \%$ \\
\hline 4 & Guru Besar & $35 \%$ & $25 \%$ & $15 \%$ & $25 \%$ \\
\hline
\end{tabular}

Berdasarkan penjelasan variabel dan tabel 4.2 Mengenai komposisi variabel yang dibutuhkan untuk dapat diajukan kenaikan pangkat setiap tenaga pendidik, maka dapat dihitung dengan menggunakan rumus sebagai berikut:

$Y=0,35 X 1+0,25 X 2+0,15 X 3+0,25 X 4$

$Z=$ Nilai yang dibutuhkan/nilai minimal yang harus dipenuhi

Keputusan Kenaikan Pangkat tenaga pendidik yang diambil:

a. Diterima/Diajukan jika $Y \geq Z$

b. Ditolak/Tidak Diajukan jika $Y<Z$

Berikut ini hasil yang sudah diolah penulis menggunakan rumus perhitungan diatas sehingga menghasilkan keputusan dengan mengambil sampel 25 orang tenaga pendidik STIE Kesatuan yaitu :

Tabel 3 Hasil Perhitungan Keputusan Kenaikan Pangkat Tenaga pendidik STIEK

\begin{tabular}{|c|c|c|c|c|c|c|c|c|c|c|}
\hline $\begin{array}{l}N \\
0\end{array}$ & $\begin{array}{l}\text { NAMA TENAGA } \\
\text { PENDIDIK }\end{array}$ & $\begin{array}{c}\text { PANGKA } \\
\text { T YANG } \\
\text { DIAJUKA } \\
\mathbf{N}\end{array}$ & $\begin{array}{l}x \\
1\end{array}$ & $\mathrm{X} 2$ & $\begin{array}{l}X \\
3\end{array}$ & $\begin{array}{l}X \\
4\end{array}$ & $Y$ & Z & $\begin{array}{c}\text { SELIS } \\
\text { IH (Y- } \\
\text { Z) }\end{array}$ & KEPUTUSAN \\
\hline 1 & $\begin{array}{l}\text { ANNARIA M } \\
\text { MARPAUNG }\end{array}$ & $\begin{array}{l}\text { Lektor } \\
\text { Kepala }\end{array}$ & $\begin{array}{l}4 \\
5\end{array}$ & 30 & 7 & $\begin{array}{l}1 \\
2\end{array}$ & 94 & $\begin{array}{c}20 \\
0\end{array}$ & -106 & $\begin{array}{l}\text { Tidak Bisa } \\
\text { Diajukan }\end{array}$ \\
\hline 2 & IRIYADI & $\begin{array}{l}\text { Guru } \\
\text { Besar }\end{array}$ & $\begin{array}{l}7 \\
9\end{array}$ & $\begin{array}{c}10 \\
0\end{array}$ & $\begin{array}{l}1 \\
5\end{array}$ & $\begin{array}{l}2 \\
3\end{array}$ & $\begin{array}{c}21 \\
7\end{array}$ & $\begin{array}{c}45 \\
0\end{array}$ & -233 & $\begin{array}{l}\text { Tidak Bisa } \\
\text { Diajukan }\end{array}$ \\
\hline 3 & MUANAS & $\begin{array}{l}\text { Lektor } \\
\text { Kepala }\end{array}$ & $\begin{array}{l}7 \\
2\end{array}$ & 85 & $\begin{array}{l}1 \\
2\end{array}$ & $\begin{array}{l}3 \\
1 \\
\end{array}$ & $\begin{array}{c}20 \\
0\end{array}$ & $\begin{array}{c}20 \\
0\end{array}$ & 0 & Bisa Diajukan \\
\hline
\end{tabular}

JAS-PT

JURNAL ANALISIS SISTEM PENDIDIKAN TINGG

ISSN $2580-5339$

elSSN $2620-5718$

Volume 5

Nomor 1

JULI 2021

Hal $49-56$ 


\begin{tabular}{|c|c|c|c|c|c|c|c|c|c|c|}
\hline $\begin{array}{l}N \\
0\end{array}$ & $\begin{array}{l}\text { NAMA TENAGA } \\
\text { PENDIDIK }\end{array}$ & $\begin{array}{c}\text { PANGKA } \\
\text { T YANG } \\
\text { DIAJUKA } \\
\mathbf{N}\end{array}$ & $\begin{array}{l}x \\
1\end{array}$ & $\mathrm{X} 2$ & $\begin{array}{l}X \\
3\end{array}$ & $\begin{array}{l}X \\
4\end{array}$ & $Y$ & Z & $\begin{array}{c}\text { SELIS } \\
\text { IH (Y - } \\
\text { Z) }\end{array}$ & KEPUTUSAN \\
\hline 4 & $\begin{array}{l}\text { DAVID H M } \\
\text { HASIBUAN }\end{array}$ & $\begin{array}{l}\text { Lektor } \\
\text { Kepala }\end{array}$ & $\begin{array}{l}8 \\
1\end{array}$ & 90 & $\begin{array}{l}2 \\
0\end{array}$ & $\begin{array}{l}2 \\
5\end{array}$ & $\begin{array}{c}21 \\
6\end{array}$ & $\begin{array}{c}20 \\
0\end{array}$ & 16 & Bisa Diajukan \\
\hline 5 & $\begin{array}{l}\text { TARIDA MARLIN } \\
\text { SURYA MANURUNG }\end{array}$ & $\begin{array}{l}\text { Lektor } \\
\text { Kepala }\end{array}$ & $\begin{array}{l}6 \\
9\end{array}$ & 71 & $\begin{array}{l}2 \\
1\end{array}$ & $\begin{array}{l}2 \\
2\end{array}$ & $\begin{array}{c}18 \\
3\end{array}$ & $\begin{array}{c}20 \\
0\end{array}$ & -17 & $\begin{array}{l}\text { Tidak Bisa } \\
\text { Diajukan }\end{array}$ \\
\hline 6 & $\begin{array}{l}\text { MUHAMMAD } \\
\text { NURUZZAMAN }\end{array}$ & $\begin{array}{l}\text { Lektor } \\
\text { Kepala }\end{array}$ & $\begin{array}{l}5 \\
4\end{array}$ & 34 & $\begin{array}{l}1 \\
4\end{array}$ & $\begin{array}{l}3 \\
1\end{array}$ & $\begin{array}{c}13 \\
3\end{array}$ & $\begin{array}{c}20 \\
0\end{array}$ & -67 & $\begin{array}{l}\text { Tidak Bisa } \\
\text { Diajukan }\end{array}$ \\
\hline 7 & $\begin{array}{l}\text { ENJANG TACHYAN } \\
\text { BUDIYANTO }\end{array}$ & $\begin{array}{l}\text { Lektor } \\
\text { Kepala }\end{array}$ & $\begin{array}{l}4 \\
2\end{array}$ & 31 & 8 & $\begin{array}{l}1 \\
1\end{array}$ & 92 & $\begin{array}{c}20 \\
0\end{array}$ & -108 & $\begin{array}{l}\text { Tidak Bisa } \\
\text { Diajukan }\end{array}$ \\
\hline 8 & HASTONI & $\begin{array}{l}\text { Lektor } \\
\text { Kepala }\end{array}$ & $\begin{array}{l}8 \\
0\end{array}$ & $\begin{array}{c}10 \\
1\end{array}$ & $\begin{array}{l}1 \\
9\end{array}$ & $\begin{array}{l}2 \\
1\end{array}$ & $\begin{array}{c}22 \\
1\end{array}$ & $\begin{array}{c}20 \\
0\end{array}$ & 21 & Bisa Diajukan \\
\hline 9 & $\begin{array}{l}\text { HARRY } \\
\text { ROESTIONO }\end{array}$ & $\begin{array}{l}\text { Lektor } \\
\text { Kepala }\end{array}$ & $\begin{array}{l}7 \\
0\end{array}$ & 86 & $\begin{array}{l}1 \\
3\end{array}$ & $\begin{array}{l}3 \\
2\end{array}$ & $\begin{array}{c}20 \\
1\end{array}$ & $\begin{array}{c}20 \\
0\end{array}$ & 1 & Bisa Diajukan \\
\hline 10 & SUTARTI & $\begin{array}{l}\text { Lektor } \\
\text { Kepala }\end{array}$ & $\begin{array}{l}8 \\
3\end{array}$ & 72 & $\begin{array}{l}2 \\
8\end{array}$ & $\begin{array}{l}2 \\
8\end{array}$ & $\begin{array}{c}21 \\
1\end{array}$ & $\begin{array}{c}20 \\
0\end{array}$ & 11 & Bisa Diajukan \\
\hline 11 & DESI EFRIANTI & Lektor & $\begin{array}{l}6 \\
7\end{array}$ & 79 & $\begin{array}{l}2 \\
8\end{array}$ & $\begin{array}{l}2 \\
4\end{array}$ & $\begin{array}{c}19 \\
8\end{array}$ & $\begin{array}{c}10 \\
0\end{array}$ & 98 & Bisa Diajukan \\
\hline 12 & JOHANES SUKADI & Lektor & $\begin{array}{l}4 \\
3\end{array}$ & 33 & $\begin{array}{l}1 \\
3\end{array}$ & $\begin{array}{l}1 \\
8\end{array}$ & $\begin{array}{c}10 \\
7\end{array}$ & $\begin{array}{c}10 \\
0\end{array}$ & 7 & Bisa Diajukan \\
\hline 13 & $\begin{array}{l}\text { DANIEL BENYAMIN } \\
\text { DE POERE }\end{array}$ & Lektor & $\begin{array}{l}8 \\
4\end{array}$ & 97 & $\begin{array}{l}1 \\
9\end{array}$ & $\begin{array}{l}2 \\
2\end{array}$ & $\begin{array}{c}22 \\
2\end{array}$ & $\begin{array}{c}10 \\
0\end{array}$ & 122 & Bisa Diajukan \\
\hline 14 & ARIEF FAHMI & Lektor & $\begin{array}{l}7 \\
6\end{array}$ & 86 & $\begin{array}{l}1 \\
4 \\
\end{array}$ & $\begin{array}{l}3 \\
2 \\
\end{array}$ & $\begin{array}{c}20 \\
8\end{array}$ & $\begin{array}{c}10 \\
0\end{array}$ & 108 & Bisa Diajukan \\
\hline 15 & AIRIN NURAINI & $\begin{array}{l}\text { Asisten } \\
\text { Ahli }\end{array}$ & $\begin{array}{l}8 \\
2\end{array}$ & 91 & $\begin{array}{l}2 \\
3\end{array}$ & $\begin{array}{l}2 \\
6\end{array}$ & $\begin{array}{c}22 \\
2\end{array}$ & $\begin{array}{c}10 \\
0\end{array}$ & 122 & Bisa Diajukan \\
\hline 16 & $\begin{array}{l}\text { JAN HORAS } \\
\text { VERYADY PURBA }\end{array}$ & $\begin{array}{l}\text { Lektor } \\
\text { Kepala }\end{array}$ & $\begin{array}{l}6 \\
7\end{array}$ & 52 & 6 & $\begin{array}{l}1 \\
2\end{array}$ & $\begin{array}{c}13 \\
7\end{array}$ & $\begin{array}{c}20 \\
0\end{array}$ & -63 & $\begin{array}{l}\text { Tidak Bisa } \\
\text { Diajukan }\end{array}$ \\
\hline 17 & SAEFUDIN ZUHDI & $\begin{array}{l}\text { Guru } \\
\text { Besar }\end{array}$ & $\begin{array}{l}7 \\
1\end{array}$ & 35 & $\begin{array}{l}1 \\
8\end{array}$ & $\begin{array}{l}1 \\
9\end{array}$ & $\begin{array}{c}14 \\
3\end{array}$ & $\begin{array}{c}45 \\
0\end{array}$ & -307 & $\begin{array}{l}\text { Tidak Bisa } \\
\text { Diajukan }\end{array}$ \\
\hline 18 & NOOR ACHMAD & $\begin{array}{l}\text { Lektor } \\
\text { Kepala }\end{array}$ & $\begin{array}{l}8 \\
2\end{array}$ & 97 & $\begin{array}{l}2 \\
7\end{array}$ & $\begin{array}{l}2 \\
3\end{array}$ & $\begin{array}{c}22 \\
9\end{array}$ & $\begin{array}{c}20 \\
0\end{array}$ & 29 & Bisa Diajukan \\
\hline 19 & $\begin{array}{l}\text { LUKMANUL HAKIM } \\
\text { AD }\end{array}$ & Lektor & $\begin{array}{l}7 \\
5\end{array}$ & 84 & $\begin{array}{l}1 \\
6\end{array}$ & $\begin{array}{l}3 \\
4\end{array}$ & $\begin{array}{c}20 \\
9\end{array}$ & $\begin{array}{c}20 \\
0\end{array}$ & 9 & Bisa Diajukan \\
\hline 20 & $\begin{array}{l}\text { BUDI HARNI ALI } \\
\text { MARAH }\end{array}$ & Lektor & $\begin{array}{l}4 \\
8\end{array}$ & 35 & 8 & $\begin{array}{l}1 \\
5\end{array}$ & $\begin{array}{c}10 \\
6\end{array}$ & $\begin{array}{c}20 \\
0\end{array}$ & -94 & $\begin{array}{l}\text { Tidak Bisa } \\
\text { Diajukan }\end{array}$ \\
\hline 21 & ANNA SETIANA & Lektor & $\begin{array}{l}7 \\
4\end{array}$ & 45 & $\begin{array}{l}1 \\
7\end{array}$ & $\begin{array}{l}2 \\
1\end{array}$ & $\begin{array}{c}15 \\
7\end{array}$ & $\begin{array}{c}10 \\
0\end{array}$ & 57 & Bisa Diajukan \\
\hline 22 & EMMY SUPARIYANI & $\begin{array}{l}\text { Guru } \\
\text { Besar }\end{array}$ & $\begin{array}{l}7 \\
3\end{array}$ & 86 & $\begin{array}{l}1 \\
5\end{array}$ & $\begin{array}{l}3 \\
0\end{array}$ & $\begin{array}{c}20 \\
4\end{array}$ & $\begin{array}{c}45 \\
0\end{array}$ & -246 & $\begin{array}{l}\text { Tidak Bisa } \\
\text { Diajukan }\end{array}$ \\
\hline 23 & NUSA MUKTIADJI & $\begin{array}{l}\text { Lektor } \\
\text { Kepala }\end{array}$ & $\begin{array}{l}8 \\
1\end{array}$ & 90 & $\begin{array}{l}2 \\
0\end{array}$ & $\begin{array}{l}2 \\
5\end{array}$ & $\begin{array}{c}21 \\
6\end{array}$ & $\begin{array}{c}20 \\
0\end{array}$ & 16 & Bisa Diajukan \\
\hline 24 & LUKMAN HIDAYAT & $\begin{array}{l}\text { Lektor } \\
\text { Kepala }\end{array}$ & $\begin{array}{l}6 \\
1\end{array}$ & 52 & $\begin{array}{l}1 \\
7\end{array}$ & $\begin{array}{l}1 \\
9\end{array}$ & $\begin{array}{c}14 \\
9\end{array}$ & $\begin{array}{c}20 \\
0\end{array}$ & -51 & $\begin{array}{l}\text { Tidak Bisa } \\
\text { Diajukan }\end{array}$ \\
\hline 25 & $\begin{array}{l}\text { ANDI YUDHA } \\
\text { AMWILA }\end{array}$ & $\begin{array}{l}\text { Asisten } \\
\text { Ahli }\end{array}$ & $\begin{array}{l}7 \\
8\end{array}$ & 84 & $\begin{array}{l}1 \\
5\end{array}$ & $\begin{array}{l}2 \\
4\end{array}$ & $\begin{array}{c}20 \\
1\end{array}$ & $\begin{array}{c}10 \\
0\end{array}$ & 101 & Bisa Diajukan \\
\hline
\end{tabular}

Sumber: data diolah

JAS-PT

JURNAL ANALISIS SISTEM PENDIDIKAN TINGGI

ISSN $2580-5339$

eISSN $2620-5718$

Volume 5

Nomor 1

JULI 2021

Hal $49-56$

DOSEN INDONESIA SEMESTA
Dari tabel Dapat diketahui bahwa tenaga pendidik yang dapat diajukan kenaikan pangkat sebanyak 15 orang tenaga pendidik sedangkan yang tidak bisa diajukan kenaikan pangkat sebanyak 10 orang tenaga pendidik dari sampel sebanyak 25 orang tenaga pendidik. Hasil perhitungan diatas dapat dijabarkan dengan mengambil salah satu sampel dengan keputusan kenaikan pangkat "Bisa Diajukan" dan salah satu sampel dengan keputusan kenaikan pangkat "Tidak Bisa Diajukan".

Tenaga pendidik atas nama Annaria M Marpaung mengajukan kenaikan pangkat menjadi Lektor Kepala dimana sebelumnya berpangkat Lektor. Nilai Pendidikan (X1) 
yang dihasilkan setelah dihitung dan dikalikan dengan prosentase dari komposisi 35\% adalah sebesar 45. Nilai Karya Ilmiah (X2) yang dihasilkan setelah dihitung dan dikalikan dengan prosentase dari komposisi $25 \%$ adalah sebesar 30 . Nilai Pengabdian (X3) yang dihasilkan setelah dihitung dan dikalikan dengan prosentase dari komposisi $15 \%$ adalah sebesar 7. Nilai Penunjang (X4) yang dihasilkan setelah dihitung dan dikalikan dengan prosentase dari komposisi $25 \%$ adalah sebesar 12 . Berdasarkan nilai-nilai $X$ yang dihasilkan maka nilai-nilai tersebut kemudian dijumlah dimana $\mathrm{X} 1+\mathrm{X} 2+\mathrm{X} 3+\mathrm{X} 4$ menghasilkan nilai total $(Y)$ dimana nilai-nilai tersebut apabila dijabarkan adalah $45+30$ $+7+12$ sehingga nilai $Y$ yang dihasilkan sebesar 94 . Nilai $Y$ tersebut kemudian dibandingkan dengan nilai minimal yang dibutuhkan untuk pangkat Lektor Kepala (Z) dimana nilai $Y$ adalah 94 dan nilai $Z$ adalah 200 sehingga terdapat selisih -106. Selisih tersebut menunjukkan bahwa nilai yang dihasilkan tenaga pendidik atas nama Annaria M Marpaung dengan pangkat yang diajukan adalah Lektor Kepala masih dianggap kurang sebesar 106 point dari nilai yang dibutuhkan sehingga dapat diambil keputusan "Tidak Bisa Diajukan" karena $Y<Z$.

Tenaga pendidik atas nama Nusa Muktiadji mengajukan kenaikan pangkat menjadi Lektor Kepala dimana sebelumnya berpangkat Lektor. Nilai Pendidikan (X1) yang dihasilkan setelah dihitung dan dikalikan dengan prosentase dari komposisi 35\% adalah sebesar 81. Nilai Karya Ilmiah (X2) yang dihasilkan setelah dihitung dan dikalikan dengan prosentase dari komposisi $25 \%$ adalah sebesar 90 . Nilai Pengabdian (X3) yang dihasilkan setelah dihitung dan dikalikan dengan prosentase dari komposisi $15 \%$ adalah sebesar 20. Nilai Penunjang (X4) yang dihasilkan setelah dihitung dan dikalikan dengan prosentase dari komposisi $25 \%$ adalah sebesar 25 . Berdasarkan nilai-nilai $X$ yang dihasilkan maka nilai-nilai tersebut kemudian dijumlah dimana $\mathrm{X} 1+\mathrm{X} 2+\mathrm{X} 3+\mathrm{X} 4$ menghasilkan nilai total $(Y)$ dimana nilai-nilai tersebut apabila dijabarkan adalah $81+90$ $+20+25$ sehingga nilai $Y$ yang dihasilkan sebesar 216 . Nilai $Y$ tersebut kemudian dibandingkan dengan nilai minimal yang dibutuhkan untuk pangkat Lektor Kepala (Z) dimana nilai $Y$ adalah 216 dan nilai $Z$ adalah 200 sehingga terdapat selisih 16. Selisih tersebut menunjukkan bahwa nilai yang dihasilkan tenaga pendidik atas nama Nusa Muktiadji dengan pangkat yang diajukan adalah Lektor Kepala melebihi nilai yang dibutuhkan sebesar 16 point sehingga dapat diambil keputusan "Bisa Diajukan" karena $Y \geq Z$.

Berdasarkan penjelasan diatas dapat dirumuskan sebagai berikut :

1. Tenaga pendidik atas nama Annaria M. Marpaung mengajukan pangkat Lektor Kepala

$Y=45+30+7+12=94$

$Z=200$

$Y-Z=94-200=-106 \rightarrow$ Kurang dari Nilai $Z$

$Y<Z \rightarrow 94<200 \rightarrow-106 \rightarrow$ "Tidak Bisa Diajukan"

2. Tenaga pendidik atas nama Nusa Muktiadji mengajukan pangkat Lektor Kepala

$Y=81+90+20+25=216$

$Z=200$

$Y-Z=216-200=16 \rightarrow$ Lebih dari Nilai $Z$

$Y \geq Z \rightarrow 216 \geq 200 \rightarrow 16 \rightarrow$ "Bisa Diajukan"

\section{SIMPULAN DAN SARAN}

Berdasarkan hasil dan bahasan tersebut maka dapat ditarik kesimpulan sebagai berikut: telah dilakukan analisis sistem kenaikan jabatan fungsional akademik, seperti analisis

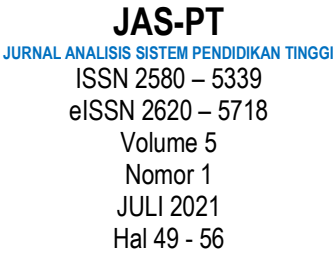


kebutuhan fungsional, analisis kebutuhan struktural, analisis proses bisnis yang sedang berjalan, analisis proses bisnis baru, telah dilakukan perancangan sistem, berupa Diagram Konteks (DFD level 0) , DFD Level 1, DFD Level 2, dan ERD. Telah dirancang, rancangan database berupa 6 tabel yaitu: tabel penulis, tabel anggota, tabel naskah, tabel kelengkapan naskah, tabel klasifikasi dan tabel editor. Telah di rancang tampilan antar muka berupa form home, form login, form tambah tenaga pendidik, form pendidikan dan pengajaran, form karya ilmiah, form pengabdian msyarakat dan form penunjang. Telah dilakukan pengembangan sistem, dengan metode waterfall dari perancangan perangkat lunak, implementasi, pengujian. Dari semula dengan manual dan sekarang dengan terkompterisasi tergambar di proses bisnis yang sedang berjalan dan proses bisnis baru. Telah dilakukan pengujian dengan melakukan pengecekan Struktural dan Fungsional untuk mengetahui sistem yang dibuat sudah sesuai atau tidak dengan rancangan.

\section{DAFTAR PUSTAKA}

Peraturan Pemerintah Repubik Indonesia No 37 Tahun 2009. "Tentang Dosen", Jakarta, 26 Mei 2009.

Gujarati, Damodar, N, 2006. "Dasar-Dasar Ekonometrika Edisi Ketiga”, Salemba Empat, Jakarta.

Undang-undang Republik Indonesia Nomor 12 Tahun 12 "Tentang Pendidikan Tinggi, Pasal 12.

Mulyana, M. (2012). Consumer Behaviour: Sukses Dengan Memahami Konsumen.

Mulyana, M., \& Puspitasari, R. (2014). Model Struktural Minat Berwirausaha Siswa SMK Di Kota Bogor. SNIT 2014, 1(1), 83-91.

Indrayani, Evi, 2005. "Sistem Informasi Manajemen Obsesi Mengoptimalkan Informasi Dalam Bisnis", Graha Ilmu, Yogyakarta.

Puntambekar, A.A, 2008. "Software Engineering First Edition", Technical Publications Pune, India.

Peraturan Menteri Pendayagunaan Aparatur Negara dan Reformasi Birokasi Republik Indonesia Nomor 46 Tahun 2013 "Perubahan atas peraturan menteri pendayagunaan aparatur negara dan reformasi birokasi Nomor 17 tahun 2013 tentang jabatan fungsional dosen dan angka kredit", 27 Desember 2013.

Sismoro, Heri, 2005. "Pengantar Logika Informatika, Algoritma, dan Pemrograman Komputer", Andi, Yogyakarta.

Al Fatta, Hanif, 2007. "Analisis \& Perancangan Sistem Informasi untuk Keunggulan Bersaing Perusahaan dan Organisasi Modern", Andi, Yogyakarta.

Sarosa, Samiaji, 2009. "Sistem Informasi Akuntansi", Grasindo, Yogyakarta.

Amyar, F., Hidayah, N. N., Lowe, A., \& Woods, M. (2019). Investigating the backstage of audit engagements: the paradox of team diversity. Accounting, Auditing \& Accountability Journal.

Astrini, D. (2020). Pendampingan Pemberdayaan Ibu-lbu Kelompok Wanita Tani Dalam Pemanfaatan Daun Sirih Sebagai Bahan Dasar Pembuatan Hand Sanitizer. Jurnal Abdimas, 4(2), 91-100.

JAS-PT

JURNAL ANALISIS SISTEM PENDIDIKAN TING

ISSN $2580-5339$

eISSN $2620-5718$

Volume 5

Nomor 1

JULI 2021

Hal 49 - 56 